\title{
ENXERTO DE TECIDO CONJUNTIVO SUBEPITELIAL: UMA OPÇÃO PARA CORREÇÃO DE DEFEITOS DE REBORDO ALVEOLAR
}

Daiane Weckerlin Fernandes NONATO; Rafael Torres BRUM

Defeitos de rebordo alveolar podem ser causados pela realização de exodontias, o que leva a um comprometimento estético importante quando na confecção da prótese que irá repor o elemento ausente, já que após uma extração dentária há alteração na topografia dos tecidos moles adjacentes, especialmente se o procedimento levar à fratura da tábua óssea vestibular. A periodontia possui algumas técnicas que quando bem indicadas são capazes de devolver volume e forma à região envolvida. Este trabalho mostra através da exposição de um caso clínico a aplicação da técnica de enxerto de tecido conjuntivo subepitelial envelopado em uma região que havia sofrido um procedimento traumático de exodontia com fratura óssea vestibular e teve a devolução de espessura e volume que possibilitou a posterior confecção de uma prótese fixa esteticamente agradável do ponto de vista do paciente. 